STUDIA ROSSICA POSNANIENSIA, vol. XL, cz. 1: 2015, pp. 49-56. ISBN 978-83-232-2878-3. ISSN 0081-6884.

Adam Mickiewicz University Press, Poznań

\title{
ТРАГИЧЕСКОЕ НАЧАЛО В ХУДОЖЕСТВЕННОМ МИРЕ ПОВЕСТИ БОРИСА ЛЬВОВИЧА ВАСИЛЬЕВА ЗАВТРА БЫЛА ВОЙНА
}

\author{
THE TRAGIC ELEMENT IN THE ARTISTIC WORLD \\ OF BORIS VASILYEV'S NOVEL TOMMOROWWAS WAR
}

\author{
АННА КАТАЖИНА ПШИБЫШ
}

\begin{abstract}
The aim of this article is to analyze the influence of war on the process of shaping personality in the young generation based on the novel Tommorow Was War which was written by Boris Vasilyev, i.e. one of the writers who survived the Second World War. The main emphasis is on the development of the heroic element in an ordinary human being, opposition to injustice, the struggle for human dignity and the issue of a moral choice.
\end{abstract}

Anna Katarzyna Przybysz, Uniwersytet im. Adama Mickiewicza w Poznaniu, Poznań - Polska.

Борис Львович Васильев принадлежит к тому поколению художников, которое пережило Великую Отечественную войну. События этого периода нашли отображение в творчестве писателя, хотя повесть Завтра была война, написанная в 1984 году, отличается от „военной тематики" его творчества. В произведении Васильева война является точкой отсчета, определяющей события, происходящие в повести, которые случились либо до, либо после нее. История в названном произведении является всего лишь фоном для показания личности героев. Именно этот факт отличает повесть автора $A$ зори здесь тихие от творчества других писателей, в которых война играла роль лейтмотива. В данном произведении Васильева она не присутствует, а „ощущается" сквозь призму чувств героев. Художник с преднамеренной тщательностью описывает их настроение, переживания. Завтра была война - это картина, представляющая созревание юного поколения предвоенной Советской России и связанные с ним вопросы нравстенного характера.

Попытка осмысления трагического в повести непременно приведет к анализу внутреннего конфликта, испытываемого дочерью Леонида Сергеевича Люберецкого. Вика - любящая дочь и комсомолка в одном лице - оказывается в непростом положении: когда ее отца обвиняют в предательстве Родины, комсомол требует от молодой де- 
вушки, чтобы та публично отреклась от своего покровителя. Девушке предстоит сделать выбор: либо встать на сторону партии, любовь к которой внушал ей отец, либо, выбирая того же отца, отказаться от комсомола. Этот выбор становится почвой для возникновения внутреннего конфликта молодой героини. Однако для того чтобы понять огромную роль идеологии Советской России в жизни молодого поколения, стоит попытаться провести глубинный анализ названия повести, не только с семантической точки зрения, но прежде всего попытаться проникуть в его суть и выявить символическое значение.

Ловкая игра слов в названии повести, своеобразный оксюморон: „завтра была" является своего рода манипуляцией временем. Создавая художественную действительность произведения, автор умело лавирирует между отдельными отрезками времени, беспрестанно вспоминая новые факты, то возвращется к прошлому, то забегает вперед, создавая таким образом фабульную линию. Композиционный прием нехронологического переплетения разных отрезков времени инспирирует читателя к вниканию в сущность поведения героев, а также дает возможность проведения углубленного, но в то же время разностороннего анализа формирования их личностей. Описывая процесс взросления молодежи, ее психического созревания, формирования взглядов, проблем нравственного характера, писатель пытается создать впечатление непредсказуемости, неожиданности. Отсюда и оксюморон: „завтра” - это будущее, то что случится с героями, то, чего читатель не знает, то, о чем сможет узнать только в эпилоге; слово „была" подчеркивает прошедшее время, время, к которому герои часто мысленно возвращаются, но которого больше нет, время неисполненных желаний, когда жизнь была впереди. Столкновение и взаимопроникновение „завтра - вчера", именно в такой последовательности, становится отличительной чертой, организующей художественную действительность во временном пространстве произведения, что и является залогом возникновения заглавного оксюморона. Названием повести Васильев подчеркивает, что первый серьезный нравственный выбор между личностным и коллективным, между правдой и абсолютной истиной, если использовать герменевтическое определение Гадамера ${ }^{1}$, героям пришлось сделать еще до начала войны. Связанное с этим выбором формирование их внутреннего мира имеет характер борьбы между внушаемой им правдой и истиной, постижение которой становится их целью. Именно момент внутренней борьбы определяется в целостном чтении произведения как созидательное личностное начало.

${ }^{1}$ Шире на эту тему в: Х.-Г. Г а д а м е р, Истина и метод: основы философской герменевтики, Москва 1988. 
Причиной возникновения внутреннего конфликта героини становится советская идеология, которой пропитано молодое поколение, резко сказавшаяся на его психике и в значительной мере влиявшая на принимаемые им решения. Именно это „историческое пространство” в сопоставлении с универсальной этикой и связанным с ней чувством преданности отцу приводит к несостыковке в мировоззрении дочери Леонида Сергеевича. Девушка чувствует угнетающее давление со строны общества, которое в большинстве уже осудило ее отца. Она понимает свое положение, знает, что ей придется доказать свою преданность комсомолу и отказаться от отца, для того, чтобы сохранить свое доброе имя и честь. Однако Леонид Сергеевич является не только авторитетом для свой дочери, но и духовным наставникам, который помогал ей разбираться в себе, в тонкостях души. С первого до последнего момента Вика твердо верит в невиновность отца, ни на секунду не сомневается в том, что человек, который научил ее любви к Родине и честной жизни, мог сотрудничать с врагами страны. Для того чтобы лучше понять, какие знамена несет внутреняя борьба героини, стоит отнестись к шелеровскому определению трагического 2 . Так, по мнению немецкого феноменолога, на данную этическую категорию огромное влияние оказывает ценностный мир героев, который, в трактовке ученого, не является константой. Морально-этические ценности кристаллизируютя под воздействием двух составляющих частей-показателей: события и времени. Первое в данной трактовке можно воспринимать как процесс воспитания героини, формирования ее внутреннего мира, моральных ценностей - то есть всего того, что приняло свою окончательную форму и проявилось в способе поведения Вики, а на что решающее влияние оказал ее отец. В оппозиции к широко понимаемым чувствам стоит время, в данном восприятии отождествляемое с политико-общественными явлениями: надвигающейся войной и зарождением тоталитарного режима. Таким образом, личность Вики Люберецкой, сформировавшаяся под влиянием вышеприведенных факторов, разделена между двумя равноправными (в ее ощущении) ценностями. Именно арест ее отца и связанные с ним последствия обуславливают возникновение той деструктивной силы, которая уничтожает душевное равновесие девушки и организует вокруг себя диссонанс в ее мировоззрении. Первичное отчаяние со временем уступает место глубокому сомнению: героиня отказывается от того, во что верила раньше, пытается заново „определить себя" и то, что было для нее важно. Поскольку в ее ощущении нельзя сделать правильный выбор, заявляясь

${ }^{2}$ M. S c h e l e r, O zjawisku tragiczności, [в:] A r y s t o t e l e s, D. H u m e, M. S c h e 1 e r, O tragedii i tragiczności, przeł. W. Tatarkiewicz, T. Tatarkiewiczowa, R. Ingarden, Kraków 1976, c. 49-95. 
на одной из сторон, единственным верным решением является смерть - самоубийство. Стоит подчеркнуть, что хотя повествователь не осуждает поступка молодой девушки, а всего лишь объективно представляет события, способ структурирования персонажа у посвященного читателя может вызвать ощущение „вины без вины” Вики Люберецкой.

Для того чтобы понять, каким образом совершенный героиней поступок, который в рамках всей повести приобретает ранг трагического жеста, оказывает влияние на других, стоит более подробно проанализировать окружение молодой героини. В качестве героев произведения Васильев „выбрал” подростковое поколение и тем самым подчеркнул отмеченную в Завтра была война проблему трагически очерченного возраста. Творческий опыт писателя позволяет читателю-соучастнику воспринимать целостность представленного мира изнутри, „осязать" события, происходящие в повести. Из-за ощущаемого предчувствия надвигающегося катастрофического времени в истории человечества героям раньше приходится принимать решения, что, по мнению автора А зори здесь тихие, существенно сказывается на процессе их взросления.

В своем произведении Васильев подчеркивает особенный разлад, диссонанс между половым созреванием героев и формированием их „взрослого” мировоззрения. Физической незрелости резко противопоставляется быстрый процесс развития их психики. Описанные переживания, сомнения, касающиеся тела и чувств, усиливают и подчеркивают молодость и неопытность молодежи, факт, что физически она только начинает созревать. Половой не-зрелости писатель резко противопоставляет быструю выработку характера, умение трезво рассуждать и принимать ответственные самостоятельные решения. На страницах повести процесс формирования зрелой психики у молодых людей начинается в тот самый момент, когда все они первый раз слушают стихи Есенина, декламируемые Викой. В перспективе видения дальнейшей судьбы героев можно предполагать, что стихотворение, прочитанное молодой девушкой, обладало особой энергией, это был своего рода импульс, сила которого заставила других задуматься и под влиянием творчества запрещенных поэтов пересмотреть внушаемую идеологией правду:

- Я прочитаю три моих любимых стихотворения одного почти забытого поэта.

- Забытое - значит, ненужное, - попытался сострить Жорка.

- Ты дурак, - сказала Вика. - Он забыт совсем по другой причине.

Она пошла на середину комнаты, раскрыла книжку, строго посмотрела вокруг и негромко начала:

Дай, Джим, на счастье лапу мне,

Такую лапу не видал я сроду...

- Это Есенин, - сказала Искра, когда Вика замолчала. Это упадочнический поэт. Он воспевает кабаки, тоску и уныние. Вика молча усмехнулась, а Зиноч- 
ка всплеснула руками: это изумительные стихи, вот и все. И-зу-ми-тель-ны-е! Искра промолчала, поскольку стихи ей очень понравились и спорить она не могла. И не хотела. Она точно знала, что стихи упадочнические, потому что слышала это от мамы, но не понимала, как могут быть упадочническими такие стихи. Между знанием и пониманием возникал разлад, и Искра честно пыталась разобраться в себе самой${ }^{3}$.

Конфликт, возникший между внушаемыми правдами и истиной, которую диктует сердце („как могут быть упадочническими такие стихи"), является исходной точкой для исследования действительности, в которой живут герои. Апогей столкновения двух противоречивых взглядов: с одной стороны, формального (мнения партии), с другой - „ощущаемой” изнутри истины пришел в момент ареста отца Вики - человека, почитаемого обществом, заслуженного героя гражданской войны, высокопоставленного чиновника. Факт, что именно господин Люберецкий дал девушкам томики поэзии запрещенных писателей, привел к тому, что спустя несколько недель его объявили врагом народа и уличили в предательстве Родины. Принятие самостоятельного выбора по отношению к литературе, мнение, что у каждого человека есть право на поиск истины, было резко наказано - Леонида Сергеевича лишили всего. Свободный, но прежде всего человеческий подход ко многим вопросам впоследствии привел к тому, что Люберецкий оказался в тюрьме, а его затравленная дочь покончила жизнь самоубийством. В своей повести Васильев далек от осуждения героини и совершенного ею поступка, который в рамках всей повести приобретает ранг трагического жеста. Четкие нравственные принципы Люберецкой в перспективе видения всей повести приобретает значение символа борьбы за свободу выбора отдельного человека и моральные ценности. Вику за явную преданность отцу, веру в его невиновность хотели исключить из комсомола, что в те времена равнялось оклеветанию. В самоотверженном акте протеста против фальшивых обвинений, не желая предавать отца, она совершает самоубийство. Решение, принятое ею, истоки которого следует искать в мировоззрении и чувстве нравственности молодой девушки, является окончательным вызовом, брошенным остальным, - вызовом сражаться за себя и свое человеческое достоинство. Стоит отметить, что стихотворением, которое Вика отважилась продекламировать своим знакомым, был стих, посвященный собаке Качалова. Выбирая это произведение, девушка, у которой не было настоящих друзей, завуалированным способом намекала своим знакомым, что она готова открыться для них, дать себя. И, наконец, после трагической жертвы, принесенной в акте протеста, она на-

3 Б.В. В а с и л ь е в, Завтра была война, Москва 2004, с. 71. 
учила других „абсолютной истине”, моральному стержню, ради которого она умерла.

Наиболее значимым ответом на призыв девушки не сдаваться был момент, когда юные друзья провожали ее в последний путь. Психически слаженный характер, а также моральные ценности, занимавшие определенное место в мировоззрении героев, толкают их на поступок, который диктует их сердце, несмотря ни на что, они решают надлежащим образом организовать своей подруге похороны. Столь важная в повести тема нравственного выбора, развертывающаяся в основной части произведения и поглащающая все остальные сюжетные линии повести, организует весьма содержательный синдром трагического акта: созидательную энергию жеста-события: самоубийства. Трагическая судьба Вики Люберецкой становится толчком, вырывает остальных из летаргического сна, но определяется также в функции зачина для постижения духовно-моральных ценностей другими героями.

Протест против укоренившихся правил наиболее глубинно находит свое отображение в стихотворении, которое Искра Полякова читает на могиле Вики. Выбор запрещенного поэта является далеко не случайным. В течение действия всей повести Сергей Александрович упоминается несколько раз. Именно его стихами (а также Грина) зачитываются молодые герои, ищущие своего пути, не умеющие определить себя и место, в котором они находятся. Поэзия Есенина дает им возможность общения с другим миром, полным чувств, страсти, полным человека как такового, как живого существа. Завершением этого „пути-поиска" своей личности, нравственности символически становится последнее предсмертное стихотворение поэта, которое в порыве страсти, охваченная чувством жалости, безвыходности, декламирует Искра. Это четверостишие на несколько мгновений заставляет собравшуюся толпу задуматься и обратить внимание на трагическое завершение недолгой жизни юной подруги.

\footnotetext{
До свиданья, друг мой, до свиданья Милый мой, ты у меня в груди.

Предназначенное расставанье

Обещает встречу впереди ${ }^{4}$.
}

Прощальное стихотворение, прочитанное героиней, несет в себе огромную эмоциональную нагрузку. Первые две строчки в перспективе видения всей повести воспринимаются как слова благодарности, как некое преклонение перед человеком, жизненная установка которого стала примером для подражания, благодаря которой взгляд других героев на жизнь, дружбу, моральность, честность изменился.

${ }^{4}$ Там же, с. 223 
„Предназначенное расставание обещает встречу впереди": уже на первых страницах произведения Искра представляется Пифией. Выбор данного стихотворения показывает, что дар, которым обладала Полякова, был неким присущим ей атрибутом. Произнося две последние строчки, героиня внутренне понимает, что ей придется разделить долю Вики, ибо такая судьба непременно ждет всех тех, у кого чувство морали не поддается корректировке, для которых ценности являются нерушимой святыней и ничто не в состоянии их уничтожить. Свобода личности, ее убеждения, в сопоставлении с твердой упрямой массой коллектива, впитавшего все коммунистические лозунги и действующего в соответствии с ними, уже изначально обречены на провал. Трагическое заключается в том, что единнственным возможным выходом из этой ситуации является смерть. Смерть становится символом протеста против царящих правил, это ярко выраженный бунт против несправедливой оценки, основанной на слухах и домыслах. Смерть, наконец, является кульминационным пунктом, заставляющим людей задуматься о правде и действительности, в которой пришлось им жить. Смерть Вики Люберецкой является своего рода событием катарсического характера. Именно ее жертва заставляет людей чувствовать, а некоторых впервые в жизни думать и действовать. Трагическое событие является зачином для постижения духовно-моральных ценностей, которые воспринимаются как конечный результат процесса взросления-преображения героев.

В повести Завтра была война представлено формирование героического начала в обычном простом человеке. Васильев демонстрирует этот процесс, фокусируясь главным образом на перемене молодой Поляковой, изменении ее взглядов, подхода к жизни и людям. Писатель показывает, как постепенно формируется характер героини, как меняется ее мировоззрение, как переоцениваются ценности. Противостояние несправедливости, борьба за человеческое достоинство, а также проблема нравственного выбора становятся предметом углубленного анализа.

Происшествия в семье Люберецких заставили Искру пересмотреть все ценности, к которым она раньше относилась как к догмам, задуматься, усомниться в той правде, в которую она безотказно верила. Знакомство с Викой и ее отцом, особенно разговоры философской натуры с Леонидом Сергеевичем, открыли ей глаза на другой мир, показали путь, о существовании которого она раныше не знала:

Искусство должно идти к мысли через чувства. Оно должно тревожить человека, заставлять болеть чужими горестями, любить и ненавидеть. А растревоженный человек пытлив и любознателен: состояние покоя и довольства собой 
порождает леность души. Вот почему мне так дороги Есенин и Блок, если брать поэтов современных [...]. Спорить не только можно, но и необходимо. Истина не должна превращаться в догму, она обязана все время испытываться на прочность и целесообразность. Этому учил Ленин, девочки. И очень сердился, когда узнавал, что кто-то стремится перелить живую истину в чугунный абсолют ${ }^{5}$.

Именно господин Люберецкий - герой гражданской войны, почитаемый обществом человек - показал юной активистке, что искусство - это не только то, что одобряет партия, это также то, в чем кроется великая жизненная правда, настоящие чувства и сомнение, в котором раньше не дано было Искре сомневаться. Благодаря отцу Вики молодая Полякова первый раз в жизни начинает „ощущать себя”, задумываться, сомневаться, ставить под вопрос то, что раньше было для нее аксиомой. Впервые в жизни она становится свободной, она больше слепо не подчиняется указаниям матери, которая твердила, что „истина - наша сила и гордость”, что „надо учить самой истине, а не способам ее доказательства”, что „человек, преданный истине, будет защищать ее с оружием в руках", что „болтовня - пустое занятие”. Смерть Вики помогла понять Искре, что человек сам для себя определяет свою истину, ту нерушимую, непоколебимую, ради которой стоит умереть. О завершении процесса психического развития свидетельствует слово-жест самоопределения: девушка первый раз в жизни принимает твердое, но непростое решение воспротивиться своей матери, которая очень долгое время была ее образцом для подражания, идеалом: „Я очень люблю тебя, мама, но если ты хоть раз, хоть один раз ударишь меня, я уйду навсегда". В словах этой молодой девушки звучит решительность, уверенность в своем поступке и некая могущественная сила, которая впервые в жизни заставила любящую дочь восстать против матери. Твердость этого решения госпожа Полякова поняла сразу, как и то, что ее маленькой дочки больше нет, что перед ней стоит взрослый человек, отвечающий за себя и свои поступки, которые ничто не в состоянии больше изменить. Болезненное, резкое решение, принятое Искрой, является отражением нравственного взросления героини. Созидательное начало трагического акта, каким была смерть Вики Люберецкой, а также поиск своего пути, как средство выражения свободы личности, права человека на определение своих собственных жизненных ценностей, с точки зрения художественной артикуляции становятся залогом изменения героев в ключе поиска „абсолютной истины”.

\footnotetext{
5 Там же, с. 93.
} 